\title{
Formation and Properties of $\mathrm{MoS}_{2} / \mathrm{C}$ Composite for Lithium Current Sources
}

\author{
L. S. Yablon, I. M. Budzulyak, O. V. Morushko, R. V. Ilnythky, \\ O. M. Hemiy, and A. I. Kachmar
}

Vasyl Stefanyk Precarpathian National University, 57 Shevchenko Str. 76018 Ivano-Frankivsk, Ukraine

In this work, the structure, physical and electrochemical properties of molybdenum disulphide/nanoporous carbon-material composites obtained by the mechanochemical-analysis and ultrasonic-dispersion methods as well as by the combination of hydrothermal method with ultrasonic treatment are investigated. The high values of specific capacitance $(1820,2205,2510$ $\mathrm{A} \cdot \mathrm{h} / \mathrm{kg}$ ) are obtained for lithium current sources (LCS) based on $\mathrm{MoS}_{2} / \mathrm{C}$ composites, which are caused by the contribution of the Faraday and capacitive processes occurring at the electrode/electrolyte interface.

В даній роботі досліджено структуру, фізичні й електрохемічні властивості композитів із дисульфіду молібдену та нанопористого вуглецевого матеріялу, одержаних методами механохемічної аналізи й ультразвукової дисперсії та комбінацією гідротермічної методи з ультразвуковим оброблення. Для літійових джерел струму (LCS) на основі композитів $\mathrm{MoS}_{2} / \mathrm{C}$ були одержані високі значення питомої ємности (1820, 2205, 2510 А·год/кг), що було зумовлено внеском як Фарадейових, так і ємнісних процесів, які відбуваються при інтерфейсі між електродою й електролітом.

В этой работе исследуются структура, физические и электрохимические свойства композитов из дисульфида молибдена и нанопористого углеродного материала, полученных методами механохимического анализа и ультразвуковой дисперсии, а также комбинацией гидротермического метода с ультразвуковой обработкой. Высокие значения удельной ёмкости $(1820,2205,2510$ А·ч/кг) были получены для литиевых источников тока (LCS) на основе композитов $\mathrm{MoS}_{2} / \mathrm{C}$, что было обусловлено вкладом как фарадеевских, так и ёмкостных процессов, которые происходят при интерфейсе между электродом и электролитом.

Key words: composite, molybdenum disulphide, nanoporous carbon, specif- 
ic capacity, lithium current sources.

Ключові слова: композит, дисульфід молібдену, нанопористий вуглець, питома ємність, літійові джерела струму.

Ключевые слова: композит, дисульфид молибдена, нанопористый углерод, удельная ёмкость, литиевые источники тока.

(Received 24 October, 2017)

\section{INTRODUCTION}

Tendencies of modern materials science consist in development of preparing low-dimensional hybrid structures that are composition of two or more different compounds. Linear dimensions of particles made of these compounds should be limited in one or more crystallographic directions down to a definite critical value. The particles with dimensions lower than this critical value possess essentially changed physics-and-chemical properties as compared with their bulk analogues. Low-dimensional materials exhibit specific electrical and electrochemical properties and possess high intercalation/deintercalation capability due to more developed specific surface. One of the components in these composites is layered structures, to which molybdenum disulphide can be related. In this compound, atomic bonds inside the layer are covalent, while interlayer interactions have the van der Waals character. $\mathrm{MoS}_{2}$ belongs to cheap and available materials that are promising electrode substances for power supply and accumulators of electric energy. Composite materials based on molybdenum disulphide with nanoporous carbon material (NCM) are of particular interest, since they exhibit an increased value of specific electrical conduction [1].

To enhance the specific capacitance and energetic characteristics of electrochemical facilities, this work was aimed at investigations of microstructure and physical properties of $\mathrm{MoS}_{2} / \mathrm{NCM}$ composites with their various percent ratios. The composites were prepared using the mechanochemical method, ultrasonic dispersion and combination of the hydrothermal method with ultrasonic treatment. Besides, to provide purposeful modification, the prepared composites were illuminated with light of YAG-laser that operated in the Qswitch mode with a definite pulse repletion frequency $(f=20-50$ $\mathrm{Hz}$ ) and energy per pulse $0.02-0.03 \mathrm{~J} / \mathrm{cm}^{2}$.

\section{OBJECTS AND METHODS OF INVESTIGATION}

$\mathrm{MoS}_{2} / \mathrm{C}$ composites with the $\mathrm{MoS}_{2}$ content from 10 up to $90 \%$ were 
obtained using the mechanochemical method and Pulverisette 6 ball mill, the rotation frequency of which reached $650 \mathrm{rev} / \mathrm{min}$, with duration of fragmentation of $20 \mathrm{~min}$.

An important feature of mechanochemical processes is the possibility to realize the so-called 'deformation mixing' (mechanical melting) the mixture components, i.e., intermixing the initial components at the atomic level. Deformation mixing takes place at relatively low temperatures, when diffusion and relaxation processes are braked that allows stabilization of various metastable intermediate products including nanodimensional particles.

Another component in this composite is carbon, atoms of which have a unique capability to create valence states with various hybridisations of atomic orbitals and provide premises to form a variety of nanocomposites based on amorphous carbon. These nanocomposites can contain even metal nanoclusters [2]. Nanoporous carbon structures of the type $a$-C that contain a mixture of nanodimensional fragments with $s p^{1}, s p^{2}$ and $s p^{3}$ bonds are of special interest, since these structures excite considerable scientific and practical interest as materials for creation of capacitance systems of superhigh capacity.

The composites were also obtained using the method of ultrasonic dispersion. As known, the dispersion process is affected by all the main effects arising in power ultrasonic fields: cavitation, sound pressure, sound-capillary effect and acoustical flows [3-5]. However, the most powerful effect is developed by cavitation that arises in solution as a result of sharp local pressure drop when the highly intense acoustic wave passes through this point. The created cavitation bubbles, moving to the range of higher pressure, close and emit secondary shock waves. In this case, the values of local pressure and temperature are increased by hundreds times. It leads to lowering the sizes of particles, which can take place in two stages [5]: at the first stage (for $5 \mathrm{~min}$ ), the rate of fragmentation increases due to friction between particles and their mutual collisions. At the second stage, these particles acquire round form, and the process slows down. At the same time, there are uncompensated physical and chemical bonds created on the surface of a particle, and these bonds are capable to activate interaction, in particular, with electrolyte ions. We realized highly efficient dispersion mixing for $25 \mathrm{~min}$ using the ultrasonic dispersant УЗДН-A operating within the frequency range 20 to $25 \mathrm{kHz}$ in water or acetonitrile.

Besides, to prepare nanocomposite $\mathrm{MoS}_{2} / \mathrm{C}$, we used the modified method [6] that combines the hydrothermal method with ultrasonic dispersion. With this aim, the mixture of $20 \mathrm{~mL} 0.1 \mathrm{M}$ ammonium heptamolybdate $\left(\mathrm{NH}_{4}\right)_{6} \mathrm{Mo}_{7} \mathrm{O}_{24} \cdot 4 \mathrm{H}_{2} \mathrm{O}, 20 \mathrm{~mL} 0.1 \mathrm{M}$ water solution of thiourea and $50 \mathrm{mg}$ of NCM was ultrasonically treated for $30 \mathrm{~min}$. 
Then, this mixture was placed into an autoclave and kept there at the temperature $493 \mathrm{~K}$ for 12 hours. The obtained black deposit was washed with water and ethanol solutions and dried at the temperature $338 \mathrm{~K}$ for 12 hours.

Crystalline structure of pure molybdenum disulphide and composites based on it was studied using x-ray diffraction analysis $\left(\mathrm{Cu} K_{\alpha^{-}}\right.$ line) within the angle range $10^{\circ}<2 \theta<90^{\circ}$.

Raman spectroscopy (RS) is a powerful tool to study microstructures and enables one to obtain information about chemical bonds, stoichiometry and determine every crystalline phase of material. The parameters of Raman bands (frequency position and halfwidth) are sensitive to features of layered structures, stresses, defects, and charged impurities. Spectra of micro-RS inherent to the studied materials were obtained using the triple spectrometer T64000 Horiba Jobin-Yvon equipped with a confocal microscope Olympus BX41 and thermoelectrically cooled CCD detector. They were registered in the back-scattering geometry at room temperature. To excite micro-RS spectra, we used the Ar-Xe laser line with the wavelength of $514.5 \mathrm{~nm}$. This radiation was focused onto the sample surface with the objective $50 \times 0.75$.

Determining the structural and adsorption characteristics of composites was performed using the method of nitrogen isothermal adsorption at the liquid nitrogen temperature $T=77 \mathrm{~K}$ with an automated sorption-meter Quantachrome Autosorb (Nova 2200e).

Images of composite surfaces were obtained using the scanning electron microscope VEGA 3 TESCAN operating at the accelerating voltage $30 \mathrm{kV}$.

To prepare the composite for further application of it as a cathode material in daylight lamps, it is pertinent to use layered molybdenum disulphide as a host matrix. The cathode and anode (lithium foil) were placed into a glass-weighing bottle filled with $1 \mathrm{M}$ solution of $\mathrm{LiBF}_{4}$ in $\gamma$-butirolaktone, which provided simultaneous chemical and electrochemical stability of this anode/cathode pair in the process of cell operation. Formation of the electrochemical cell was performed in a dry preparation box in argon atmosphere and under the presence of $\mathrm{P}_{2} \mathrm{O}_{5}$.

Discharge curves were obtained during the galvanostatic discharge at the value of current $0,3 \mathrm{C}$ within the range of potentials 0 to $3 \mathrm{~V}$ with the special facility TIONiT P2.00-xx and software, which provided controlling these electrochemical processes and data manipulation 'Multicycle 2.0×'.

\section{RESULTS AND DISCUSSION}

To provide a correct analysis of experimental diffractograms (Fig. 


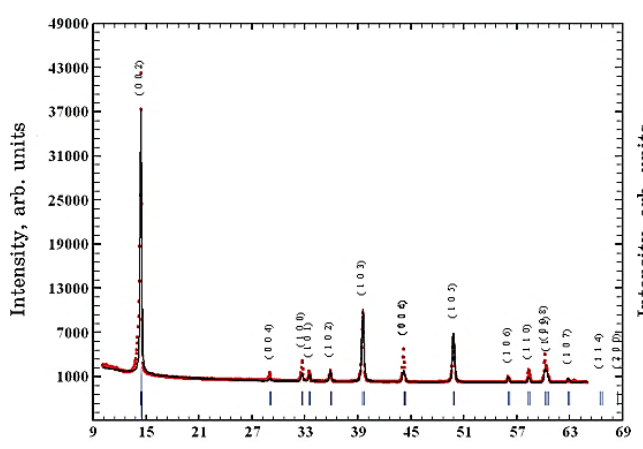

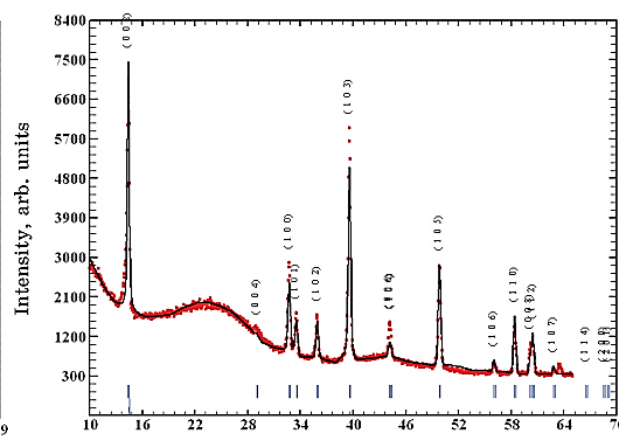

Fig. 1. Approximation of experimental diffractograms by the FullProf program for the $\mathrm{MoS}_{2}(a)$ and the $\mathrm{MoS}_{2} / \mathrm{C}$ composite (b), taking into account the March-Dollase model texture.

1), we used the texture model by March-Dollase [7], which is described by the following formula:

$$
T_{h k l}=\frac{1}{N} \sum_{i=1}^{N}\left(\tau^{2} \cos ^{2} \phi_{h k l}^{i}+\frac{1}{\tau} \sin ^{2} \phi_{h k l}^{i}\right)^{-3 / 2},
$$

where $T_{h k l}$ is the normalization coefficient providing correction of the intensity for the reflection peak from the plane $(h k l) ; N-$ number of symmetric equivalent reflections; $\phi_{h k l}^{i}$-angle between the basis direction and the normal to the lattice plane; $\tau$-variable March parameter that defines the part of grains oriented randomly in the sample:

$\tau<1$ for lamellar crystals $\left(T_{\|}>T_{\perp}\right)$;

$\tau=1$ for disordered system $\left(T_{\|}=T_{\perp}\right)$;

$\tau>1$ for needle-shaped crystals $\left(T_{\|}<T_{\perp}\right)$.

When using this model in the PowderCell program, we calculated the value of this parameter $\tau$. It is equal to 0.63 , which is indicative of a lamellar character of $\mathrm{MoS}_{2}$ crystals. Also, we calculated the lattice parameters of these crystals $(a=0.3163 \mathrm{~nm}, c=1.22948 \mathrm{~nm})$.

With account of a complex background inherent to the obtained $\mathrm{x}$-ray diffractograms and impossibility to correctly approximate it in the frame of the PowderCell program, we used also the FullProf software that enables to set this background by various ways. Figure 1 shows the results of approximating the experimental diffractograms with this program for pure $\mathrm{MoS}_{2}$ with account of its texture, if the March-Dollase model is used.

In Figure 1, $b$, the diffractogram of $\mathrm{MoS}_{2} / \mathrm{C}$ composites prepared using the mechanochemical way is shown. There are available all 


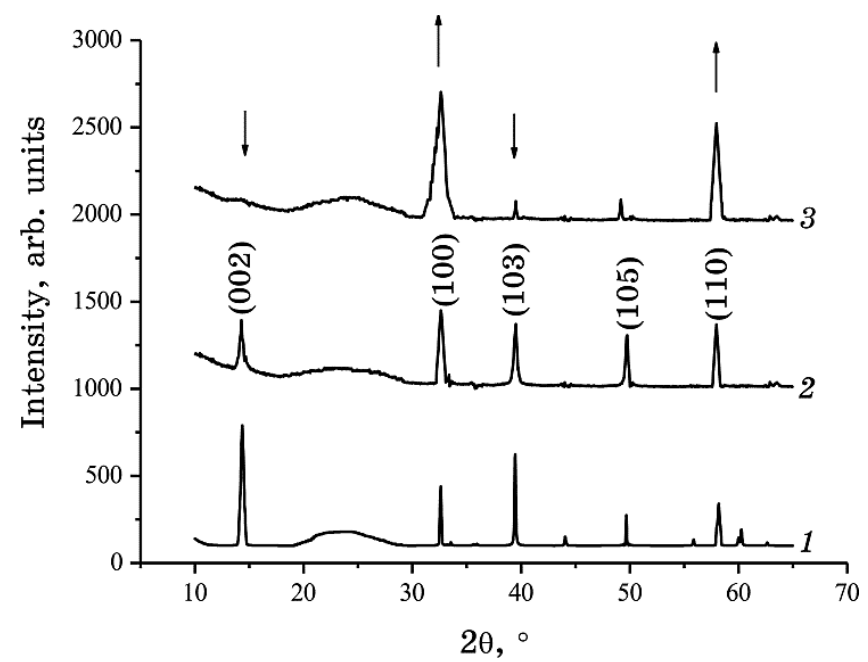

Fig. 2. X-ray diffraction diffractogram of the composite $\mathrm{MoS}_{2} / \mathrm{C}=30 / 70$ : 1-laser irradiated; 2-obtained by ultrasonic dispersion; 3-obtained by a combination of hydrothermal technique with ultrasonic dispersion.

the typical peaks of the $2 \mathrm{H}-\mathrm{MoS}_{2}$ crystalline structure. Their intensity is decreased with increasing the content of NCM. Within the angle range $16-30^{\circ}$, one can observe the amorphous halo corresponding to carbon, its intensity grows with increasing the amount of carbon.

Laser irradiation and ultrasonic treatment of the composites (Fig. 2 , curves 1 and 2) results in decreasing the number of reflections in diffractograms, however, the main peaks typical for the $2 \mathrm{H}-\mathrm{MoS}_{2}$ crystalline structure are available. Besides, within the range of angles $18-30^{\circ}$, one can observe the amorphous halo corresponding to NCM. It is interesting that ultrasonic dispersion and hydrothermal treatment (Fig. 2, curves 2 and 3 ) result in the growing intensity of the (100) and (110) peaks as well as in decreasing the intensity of the (103) and (002) peaks. This behaviour is inherent to the nanodispersed state of substance.

In the composite $\mathrm{MoS}_{2} / \mathrm{C}$ prepared using the hydrothermal method in combination with ultrasonic treatment (Fig. 2, curve 3), the peak (002) is not observed in general, which, in accord with [8], indicates formation of graphene-like material, where bonds between separate $\mathrm{MoS}_{2}$ layers are absent.

These assumptions are confirmed by SEM images of the composites $\mathrm{MoS}_{2} / \mathrm{C}$ prepared using ultrasonic dispersion (Fig. 3, a) combined with hydrothermal synthesis and ultrasonic treatment (Fig. 3, $b$ ), which shows that these preparation methods result in different surface morphology. The $\mathrm{MoS}_{2} / \mathrm{C}$ composite prepared by ultrasonic 

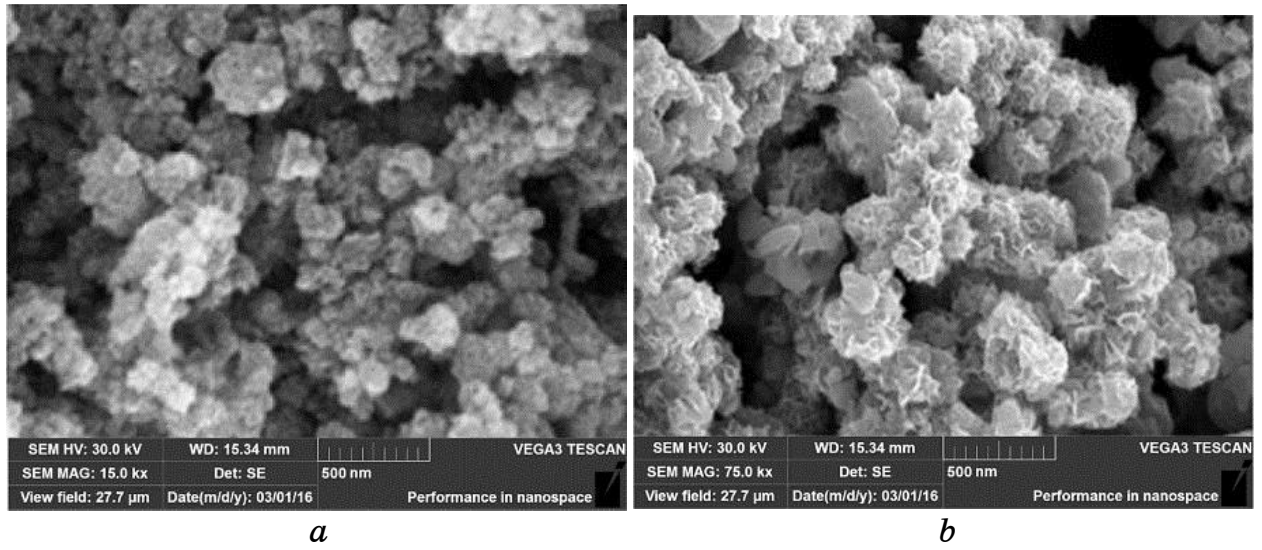

Fig. 3. SEM images of the surface of composite $\mathrm{MoS}_{2} / \mathrm{C}$ obtained by: (a) ultrasonic dispersion in acetonitrile; $(b)$ combination of hydrothermal synthesis with the action of ultrasound.

dispersion in acetonitrile is an aggregate of agglomerated spherelike nanoparticles, which are mainly created due to cavitation and solvent, molecules of which increase interlayer distances in molybdenum disulphide and lead to weakening interaction between layers and creation of nanoparticles.

As seen from Figure $3, b$, the hydrothermal method in combination with ultrasonic treatment enabled to obtain material in the form of a set of flower-like nanoparticles, which indicates the porous structure of this material. Distances between layers of nanosheets from flower-like nanoparticles can serve as transport channels for electrolyte ions as well as increase the specific area of nanocomposite surface. Besides, this structure increases stability of the obtained material [6].

The structural and adsorption characteristics estimated using DFT [9] indicate that the specific area of the composite prepared using combination of hydrothermal synthesis and ultrasonic treatment is close to $556 \mathrm{~m}^{2} / \mathrm{g}$, which is almost two times higher than the surface specific area in the composite obtained using only ultrasonic dispersion and more than seven times higher as compared with that for $\mathrm{MoS}_{2} / \mathrm{C}$ prepared using the mechanochemical method.

$\mathrm{MoS}_{2}$ belongs to the spatial group $P 6_{3} / m m c$ (point group $D_{6 h}$ ) with the unit cell consisting of two Mo atoms in positions with the point group $D_{3 h}$ and four $\mathrm{S}$ atoms in positions of the point group $C_{3 v}$ [10]. The Raman spectra peak intensities for crystalline $\mathrm{MoS}_{2}$ differ from the intensities of the same peaks for small-layer molybdenum disulphides [11]. As known [12], the main features of Raman spectra in the majority of studied molybdenum disulphides are availabil- 
ity of four modes: $E_{2 g}^{2}\left(32 \mathrm{~cm}^{-1}\right), E_{1 g}\left(286 \mathrm{~cm}^{-1}\right), E_{2 g}^{1}\left(383 \mathrm{~cm}^{-1}\right)$, $A_{1 g}\left(408 \mathrm{~cm}^{-1}\right)$. The $\AA_{1 g}$ mode corresponds to the so-called 'out-ofplane' vibrations of sulphur atoms relatively to the plane (001) (Fig. 4 ), while the other three modes correspond to vibrations of molybdenum and sulphur atoms in the basis plane, i.e., 'in-plane' vibrations [13].

The micro-RS spectrum in the studied $\mathrm{MoS}_{2}$ (Fig. 5) is characterized by availability of two clearly pronounced maxima that can be related to $E_{2 g}^{1}\left(381 \mathrm{~cm}^{-1}\right)$ and $A_{1 g}\left(407 \mathrm{~cm}^{-1}\right)$ modes as well as one less pronounced maximum $-E_{1 g}$ mode $\left(284 \mathrm{~cm}^{-1}\right)$. The frequency position, half-width, ratio of intensities, and difference in spectral positions of these bands enable to obtain information on structural

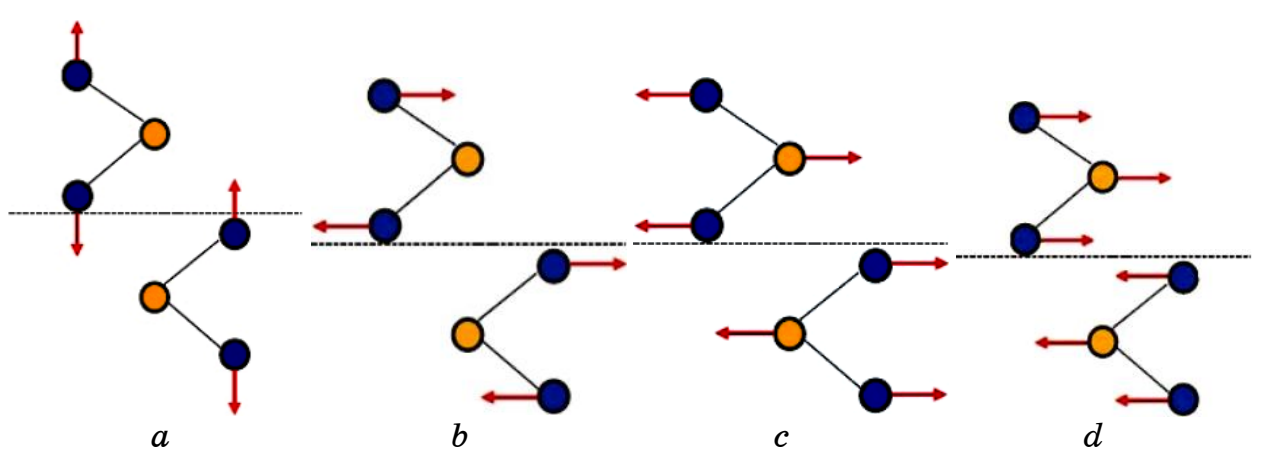

Fig. 4. The vector of the displacement of Mo (O) and $S(O)$ atoms in the $\mathrm{MoS}_{2}$ crystal corresponding to the phonon modules $A_{1 g}, E_{1 g}, E_{2 g}^{1}, E_{2 g}^{2}$, which are active in the first-order microcircuit spectra with inverse scattering in the direction [100].

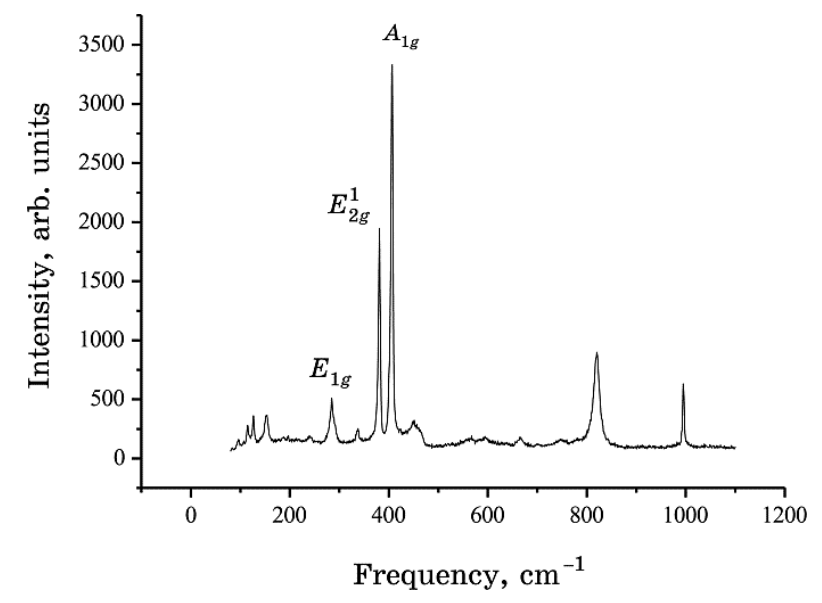

Fig. 5. Micro-RS spectrum $\mathrm{MoS}_{2}$. 
perfection of the $\mathrm{MoS}_{2}$ layered crystal and number of structure layers. When the number of layers is decreased from that of bulk to monolayer state, frequency positions of $A_{1 g}$ and $E_{2 g}^{1}$ bands are changed along with the spectral distance between them [14]. In particular, $E_{2 g}^{1}$ band is shifted to the high-frequency range by $2 \mathrm{~cm}^{-1}$ (while this value for bulk $\mathrm{MoS}_{2}$ reaches $383 \mathrm{~cm}^{-1}$ ). At the same time, $A_{1 g}$ band is approximately shifted by $4 \mathrm{~cm}^{-1}$ to the lowfrequency side (as compared with $408 \mathrm{~cm}^{-1}$ in bulk $\mathrm{MoS}_{2}$ ), and the respective distance between them is decreased from $25 \mathrm{~cm}^{-1}$ down to $19 \mathrm{~cm}^{-1}$ [14].

In our case, there observed are insignificant shifts of frequency positions inherent to these bands to the low-frequency side (Table 1 ), and the distance between the bands is equal to $26 \mathrm{~cm}^{-1}$, which, in opinion of the authors [14], can be explained by internal stresses in these crystals. Thus, the main characteristics of $E_{2 g}^{1}$ and $A_{1 g}$ bands as well as the ratio of their intensities correspond to those of bulk crystal $2 \mathrm{H}-\mathrm{MoS}_{2}$. The observed difference between them as compared with the ideal crystal $\mathrm{MoS}_{2}$ can be explained by availability of internal stresses and structural disorder.

Besides, it becomes possible to register the low-frequency $E_{1 g}$ mode-the band of weak intensity at $\sim 286 \mathrm{~cm}^{-1}$ (Fig. 2). The low intensity of the latter is often related to polarization effects [13], this mode is forbidden for $s$-polarized light incident onto the surface of $\mathrm{MoS}_{2}$ crystal (vector of the electric field is directed along the normal to the crystal axis $c$ ). At the same time, for $p$-polarized light this $E_{1 g}$ mode is of high intensity.

Adduced in Table 1 are the positions of peaks in micro-RS spectra for the studied material, when using the exciting wavelength of $514.5 \mathrm{~nm}$ with the power of $100 \mathrm{~mW}$. As seen, this sufficiently high light power enables to find new groups of bands near 995 and $820 \mathrm{~cm}^{-1}$. Probably, these bands can be related to vibration states of $\mathrm{MoO}_{3}$ [12], which indicates oxidation induced by the high-power laser light, particularly in accord with the following reaction:

$$
\mathrm{MoS}_{2}+3 \frac{1}{2} \mathrm{O}_{2} \rightarrow \mathrm{MoO}_{3}+2 \mathrm{SO}_{2} .
$$

Availability of the asymmetric peak near $452 \mathrm{~cm}^{-1}$ is explained by the authors [15] via superposition of the second-order processes, namely, scattering of longitudinal acoustical phonon ( $E_{1 u}^{2}$ mode) and resonance effect ( $A_{2 u}$ mode). This peak can be also explained as the presence of $\mathrm{MoO}_{2}$ inclusions in the sample [16].

As follows from the $\mathrm{x}$-ray diffractometric analysis [1], mechanochemical mixing $\mathrm{MoS}_{2}$ and NCM results in changing the parameters of crystalline lattice and appearance of mechanical stresses, which, as a rule, leads to the shifts of frequency positions of $A_{1 g}, A_{2 g}^{1}$ 
TABLE 1. The position of the maximums of the micro-RS $\mathrm{MoS}_{2}$.

\begin{tabular}{c|c|c|c|c|c|c|c}
\hline Mode & $E_{2 g}^{1}$ & $E_{1 g}$ & $E_{2 g}^{1}$ & $A_{1 g}$ & $E_{1 u}^{2} A_{2 u}$ & $2 A_{1 g}$ & $A_{1 g} B_{1 g}$ \\
\hline Frequency, $\mathrm{cm}^{-1}$ & 153 & 284 & 381 & 407 & 452 & 820 & 995 \\
\hline
\end{tabular}

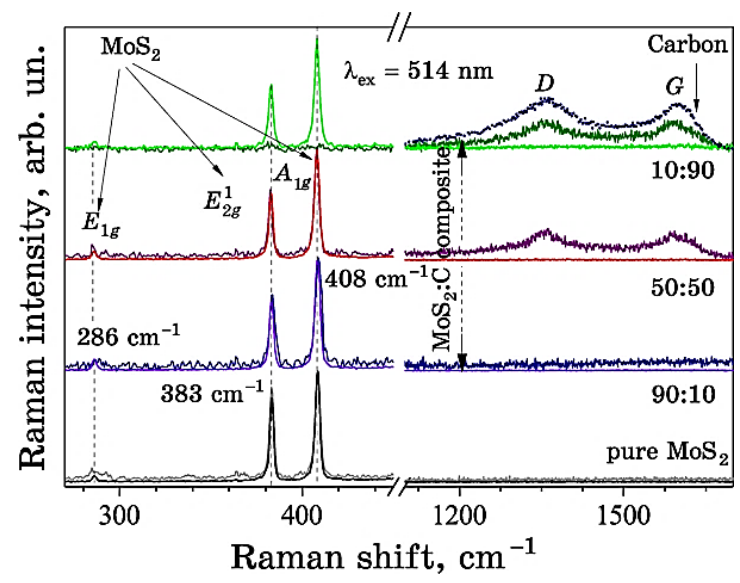

Fig. 6. Micro-RC spectra of pure $\mathrm{MoS}_{2}$ and $\mathrm{MoS}_{2} / \mathrm{C}$ composites with different contents of NCM.

bands as well as their widening as compared with an ideal crystal. It is that is observed in our case (Fig. 6). In addition, as seen from Fig. 7, both bands are shifted in the same direction, either to the high- or low-frequency side, the distance between them remains practically unchanged: $25.1 \pm 0.1 \mathrm{~cm}^{-1}$.

In the micro-RS spectra of $\mathrm{MoS}_{2} / \mathrm{C}$, there are also registered two phonon bands of the weak intensity, the so-called $G$ ('Graphitic') and $D$ ('Defect') bands near 1594 and $1350 \mathrm{~cm}^{-1}$, respectively, appearance of which is caused by single-phonon processes of inelastic light scattering on valence vibrations inherent to $s p^{2}$-bonded carbon atoms as well as scattering on structural defects [17]. It is noteworthy that the carbon bands can be clearly registered in the composites with the ratios of components $\mathrm{MoS}_{2}: \mathrm{C}$ equal to 50:50 and 10:90 (Fig. 6). Their shape corresponds to that in the carbon amorphous phase [18] and is similar to that in pure carbon powder.

The micro-RS spectra of $\mathrm{MoS}_{2} / \mathrm{C}$ composites treated with laser radiation and ultrasound as well as those processed with the combined method of hydrothermal synthesis and ultrasonic action are characterized by the presence of signals for the modes $A_{1 g}, E_{2 g}^{1}$. As seen from Table 2, laser irradiation leads to shifting the peaks of both modes to the high-frequency range, which is related with laser thermal action [14]. 

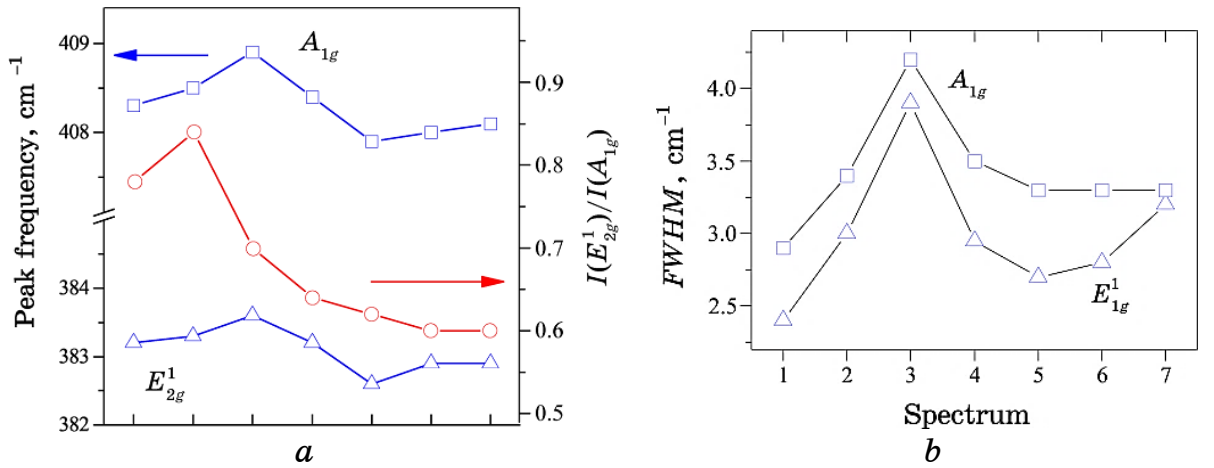

Fig. 7. Evolution of the frequency position and the bands of the samples under study: $(a)$ ratio of their intensities; $(b)$ half-width. Points 1, 2 correspond to pure $\mathrm{MoS}_{2}$; points 3-7 correspond to composites containing NCM: 10\% (p. 3, 4), 50\% (p. 5, 6), 90\% (p. 7).

TABLE 2. The position of the modes $A_{1 g}$ and $E_{2 g}^{1}$ micro-RS $\mathrm{MoS}_{2} / \mathrm{C}$ composite.

\begin{tabular}{c|c|c}
\hline Material & $\begin{array}{c}\text { Frequency of mode peak } E_{2 g}^{1}, \\
\mathrm{~cm}^{-1}\end{array}$ & $\begin{array}{c}\text { Frequency of mode peak } A_{1 g}, \\
\mathrm{~cm}^{-1}\end{array}$ \\
\hline $\mathrm{MoS}_{2} / \mathrm{C}$ & 382.8 & 408 \\
$\mathrm{MoS}_{2} / \mathrm{C}, L^{*}$ & 383 & 408.9 \\
$\mathrm{MoS}_{2} / \mathrm{C}, U S^{*}$ & 383.5 & 406.5 \\
$\mathrm{MoS}_{2} / \mathrm{C}, G S^{*}$ & 384.5 & 404.1 \\
\hline
\end{tabular}

$L^{*}$-laser irradiated composite; $U S^{*}$-composite obtained by ultrasonic dispersion; $G S^{*}-$ hydrothermally synthesized composite.

The ultrasonic treatment and modified method for preparation of the composites result in changing surface morphology and, consequently, in another interaction between atoms of sulphur, molybdenum and carbon. Thus, the change in frequencies of $A_{1 g}, E_{2 g}^{1}$ modes can be explained within the framework of the van der Waals interaction [13]. With increasing the distance between the layers of molybdenum disulphide, forces of $\mathrm{S}-\mathrm{S}$ bonds are weakened, which corresponds to lowering the frequency of the out-of-plane mode $A_{1 g}$. At the same time, the peak of $E_{2 g}^{1}$ mode is shifted to the highfrequency range, which is indicative of transition from the bulk structure to the single- or several-layer one. It is confirmed by the authors [13]. Since the classical model for coupled harmonic oscillators that takes into account only weak interlayer interaction cannot explain this fact, then some additional interaction between layers should take place. In [19], this additional interaction is explained by the model of the long-range Coulomb force and the decreasing 
distance $\mathbf{S}-\mathrm{Mo}-\mathrm{S}$ in small-layer structures, which, in our case, can be caused by embedding the carbon atoms into the interlayer space of molybdenum disulphide under ultrasonic action.

As the influence of laser irradiation, ultrasonic treatment and hydrothermal processing enables to obtain materials with the increased amount of host positions, lowered sizes of nanoparticles, high surface specific area and, respectively, high electric conduction, then these materials used by us as cathodes for LCS.

As seen from Figure 8, on discharge curves for electrochemical cells with cathodes based on modified composites, when these curves are measured at the discharge current $0.3 \mathrm{C}$, in the first cycle, there are observed two plateaus in the vicinities of 1.1 and $0.5 \mathrm{~V}$ that corresponds to intercalation of lithium ions into the composites in accord with the following reactions [20]:

$$
\mathrm{MoS}_{2}+x \mathrm{Li}^{+}+x e^{-} \rightarrow \mathrm{Li}_{x} \mathrm{MoS}_{2}, x \mathrm{Li}^{+}+x e^{-}+\mathrm{C} \rightarrow \mathrm{Li}_{x} \mathrm{C}
$$

and

$$
\mathrm{Li}_{x} \mathrm{MoS}_{2}+(4-x) \mathrm{Li}^{+}+(4-x) e^{-} \rightarrow 2 \mathrm{Li}_{2} \mathrm{~S}+\mathrm{Mo},
$$

respectively.

Intercalation of lithium ions into molybdenum disulphide is possible firstly due to the fact that valent electron states of lithium atoms are characterized by higher energy than the empty conduction bands related to molybdenum cations in $\mathrm{MoS}_{2}$ (first of all, it concerns $4 d$ orbital). Besides, the influence of laser irradiation or ultrasonic treatment causes growth of the lattice parameter $c$,

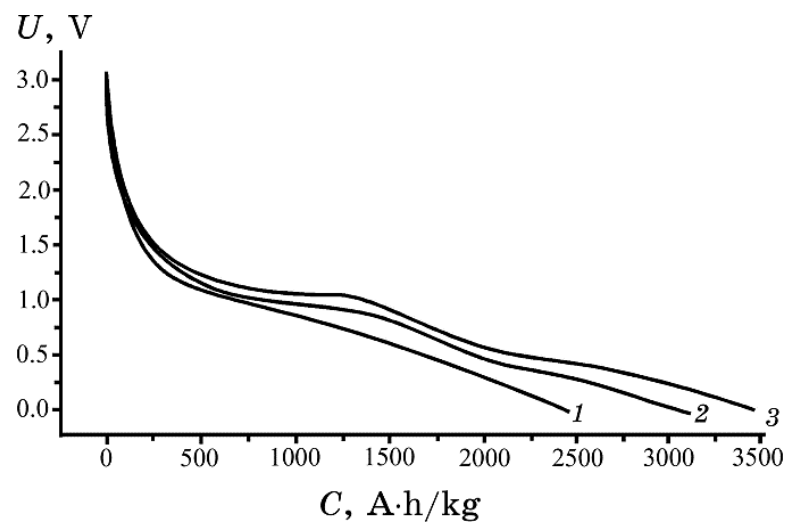

Fig. 8. The discharge curves for a LCS with a cathode: $1-$ a laser irradiated composite $\mathrm{MoS}_{2} / \mathrm{C} ; 2-\mathrm{MoS}_{2} / \mathrm{C}$ composite obtained by ultrasonic dispersion; $3-\mathrm{MoS}_{2} / \mathrm{C}$ composite obtained by the modified method. 
which results in elongation of $\mathrm{S}-\mathrm{S}$ bonds and promotes better entry of lithium ions into interlayer spaces of $\mathrm{MoS}_{2}$ at the initial intercalation moment.

However, the effect of increasing the surface specific area due to lowering the particle sizes and creation of sphere- or flower-like nanoparticles under action of ultrasound or hydrothermal synthesis, as it is expected, will remain to be effective during all the period of electrode functioning. In this case, lithium ions occupy vacant octahedral positions in the hexagonal crystalline lattice [20], since occupation of tetrapositions needs higher energy [21]. Transfer of lithium ions into $\mathrm{MoS}_{2}$ depends not only on availability of high concentration of charge carriers, vacancies and interstitial voids. It is tightly related with the low activation energy for ion hops to create the triple compound $\mathrm{Li}_{x} \mathrm{MoS}_{2}$. If the host occupation with lithium $x$ becomes lower than $\mathbf{0 . 1}$, than intercalation of lithium ions into $\mathrm{MoS}_{2}$ takes place with insignificant disturbance of the host lattice. When the concentration of lithium ions increases, there occurs addition of one or more electrons to the host phase with creation of the ion $\left(\mathrm{MoS}_{2}\right)^{-}$, which causes distortion of octahedral positions inherent to molybdenum cations and, as a result, leads to significant changes in the host electron structure [20]. Thus, it is observed the phase transition: crystalline lattice of $\mathrm{MoS}_{2}$ converts from $2 \mathrm{H}$ phase to $1 T$ one. This transition is often related to the plateau in galvanostatic discharge curves in the vicinity of $1.1 \mathrm{~V}$ [22]. The plateau around $0.5 \mathrm{~V}$ can be related with progressive changing the processes, namely: at the initial stage, there takes place decomposition of $\mathrm{MoS}_{2}$ down to particles of Mo and their embedding into the matrix $\mathrm{Li}_{2} \mathrm{~S}$, then creation of a gel-like polymer layer occurs through degradation of electrolyte [23].

Using the galvanostatic method, we obtained the following values for the specific capacitance of $\mathrm{MoS}_{2} / \mathrm{C}$ composites irradiated with laser, treated with ultrasound or with the modified method: 1820, $2205,2510 \mathrm{~A} \cdot \mathrm{h} / \mathrm{kg}$, respectively, and the specific energy in these cases reached $1980,2420,2750 \mathrm{~W} \cdot \mathrm{h} / \mathrm{kg}$. As the authors of [24-26] believe, the nanostructures (in particular, nanosheets, nanofullerenes) are characterized by a high density of defects in the form of vacancies (mainly vacancies of sulphur), which enhances reaction capability due to availability of broken bonds. It is quite probable that these centres play the role of adsorption positions for lithium ions and serve to explain these high values of specific capacitance and energetic characteristics of LCS in the first cycle of exploitation.

Thus, the important role is played here by the fast reversible Faraday processes that occur in $\mathrm{MoS}_{2}$ as well as the high conduction of NCM. 


\section{CONCLUSIONS}

It has been shown that $\mathrm{MoS}_{2} / \mathrm{C}$ composite prepared using ultrasonic dispersion in acetonitrile is the aggregate of agglomerated spherelike nanoparticles that are created due to an important role of cavitation. The hydrothermal method in combination with ultrasonic treatment enabled to obtain the porous structure in the form of a set of flower-like nanoparticles with the diameter 100 to $200 \mathrm{~nm}$. The space between layers of nanosheets consisting of flower-like nanoparticles serve as transport channels for electrolyte ions and increase the surface specific area of composite (up to $556 \mathrm{~m}^{2} / \mathrm{g}$ ).

It has been ascertained that laser irradiation of $\mathrm{MoS}_{2} / \mathrm{C}$ composite causes shift of the peaks inherent to $A_{1 g}, E_{2 g}^{1}$ modes in micro-RS spectra to the high-frequency range because of laser light thermal action. The ultrasonic treatment and laser irradiation of composites lead to changes in surface morphology and, consequently, to changes in the character of interaction between atoms of sulphur, molybdenum and carbon. With increasing the distance between $\mathrm{MoS}_{2}$ layers, forces of $\mathrm{S}-\mathrm{S}$ bonds are weakened, which corresponds to lowering the peak frequency of the out-of-plane mode $A_{1 g}$. At the same time, the peak of $E_{2 g}^{1}$ mode shifts to the high-frequency range, which is indicative of transformation from the bulk structure to the single- or several-layer one.

For the first time, we have obtained so high values of specific capacitance and specific energy $(1820,2205,2510 \mathrm{~A} \cdot \mathrm{h} / \mathrm{kg}$ and $1980,2420,2750 \mathrm{~W} \cdot \mathrm{h} / \mathrm{kg}$, respectively) for LCS based on $\mathrm{MoS}_{2} / \mathrm{C}$ composites. To enhance their functional performances, we have processed these composites with laser irradiation, ultrasonic treatment and combination of hydrothermal treatment and ultrasound, which provides realization of the Faraday and capacitance processes at the electrode/electrolyte interface. However, dominating contribution to these high values of specific capacitance and energy is provided just by redox-reactions taking place in the nanocomposites due to the high density of defects in the form of vacancies capable to adsorb lithium ions.

\section{REFERENCES}

1. I. M. Budzulyak, M. V. Karpeth', L. S. Yablon et al., Journal of Nano- and Electronic Physics, 8, No. 2: 02029-1 (2016) (in Ukrainian).

2. S. H. Yastrebov, V. I. Ivanov-Omsky, F. Dumitrache, and K. Moroshanu, Semiconductors, 37, No. 4: 490 (2003) (in Russian).

3. B. A. Ahranat, M. N. Dubrovin, and N. N. Havsky. Osnovy Fiziki i Tekhniki Ultrazvuka [Fundamentals of Physics and Technology of Ultrasound] (Moscow: Vysshaya Shkola: 1987) (in Russian). 
4. V. L. Lanin, N. V. Dyejkunov, and A. V. Kotuhov, Surface Engineering and Applied Electrochemistry, 3: 28 (2010) (in Russian).

5. P. H. Dumitrash and M. K. Bologa, Surface Engineering and Applied Electrochemistry, 2: 71 (2007).

6. Manas Mandal, Debasis Ghosh, Swinderjeet Singh Kalra, Chapal Kumar Das, International Journal of Latest Research in Science and Technology, 3, No. 3: 65 (2000).

7. $\quad$ E. Zolotoyabko, Journal of Applied Crystallography, 42: 513 (2009).

8. L. Ma, G. Huang, W. Chen et al., Journal of Power Sources, 264: 262 (2014).

9. R. O. Jones and O. Gunnarsson, Rev. Mod. Phys., 61, No. 3: 689 (1989).

10. X. Zhang, W. P. Han, J. B. Wu, S. Milana, Y. Lu, Q. Q. Li, A. C. Ferrari, and P. H. Tan, Physical Review B, 87: 115413-1 (2013).

11. H. Li, Q. Zhang, Ch. Chong Ray Yap, B. Kang Tay, T. Hang Tong Edwin, A. Olivier, and D. Baillargeat, Adv. Funct. Mater., 22: 1385 (2012).

12. B. C. Windom, W. G. Sawyer, and D. W. Hahn, Tribol. Lett., 42, No. 3: 301 (2011).

13. M. Ye, D. Winslow, D. Zhang, R. Pandey, and Y. Khin Yap, Photonics, 2: 288 (2015).

14. S. Najmaei, Z. Liu, P.M. Ajayan, and J. Lou, Appl. Phys. Lett., 100: 013106 (2012).

15. G. L. Frey, R. Tenne, M. J. Matthews, M. S. Dresselhaus, and G. Dresselhaus, Phys. Rev. B, 60, No. 121: 2883 (1999).

16. L. Ma, W.-X. Chen, Z.-D. Xu, J.-B. Xia, and X. Li, Nanotechnology, 17: 571 (2006).

17. B. Krauss, T. Lohmann, D.-H. Chae, M. Haluska, K. von Klitzing, and J. H. Smet, Phys. Rev. B, 79: 165428 (2009).

18. A. C. Ferrari and J. Robertson, Phys. Rev. B, 61: 20: 14095 (2000).

19. A. Molina-Sanchez and L. Wirtz, Phys. Rev. B, 84: 155413 (2011).

20. T. Stephenson, Z. Li, B. Olsen, and D. Mitlin, Energy Environ. Sci., 7: 209 (2014).

21. K. Chrissafis, M. Zamani, K. Kambas et al., Mater. Sci. Eng. B, 3: 145 (1989).

22. X. Fang, X. Guo, Y. Mao et al., Asian Journal of Chemistry, 7: 1013 (2012).

23. K. Chang and W. X. Chen, ACS Nano, 5: 4720 (2011).

24. M. A. Py and R. R. Haerin, Can. J. Phys, 61: 76 (1983).

25. P. J. Mulhe, Can. J. Phys., 67: 1049 (1989).

26. M. Wang, G. Li, H. Xu et al., American Chemical Society Appl. Mater. Interfaces, 5: 1003 (2013). 